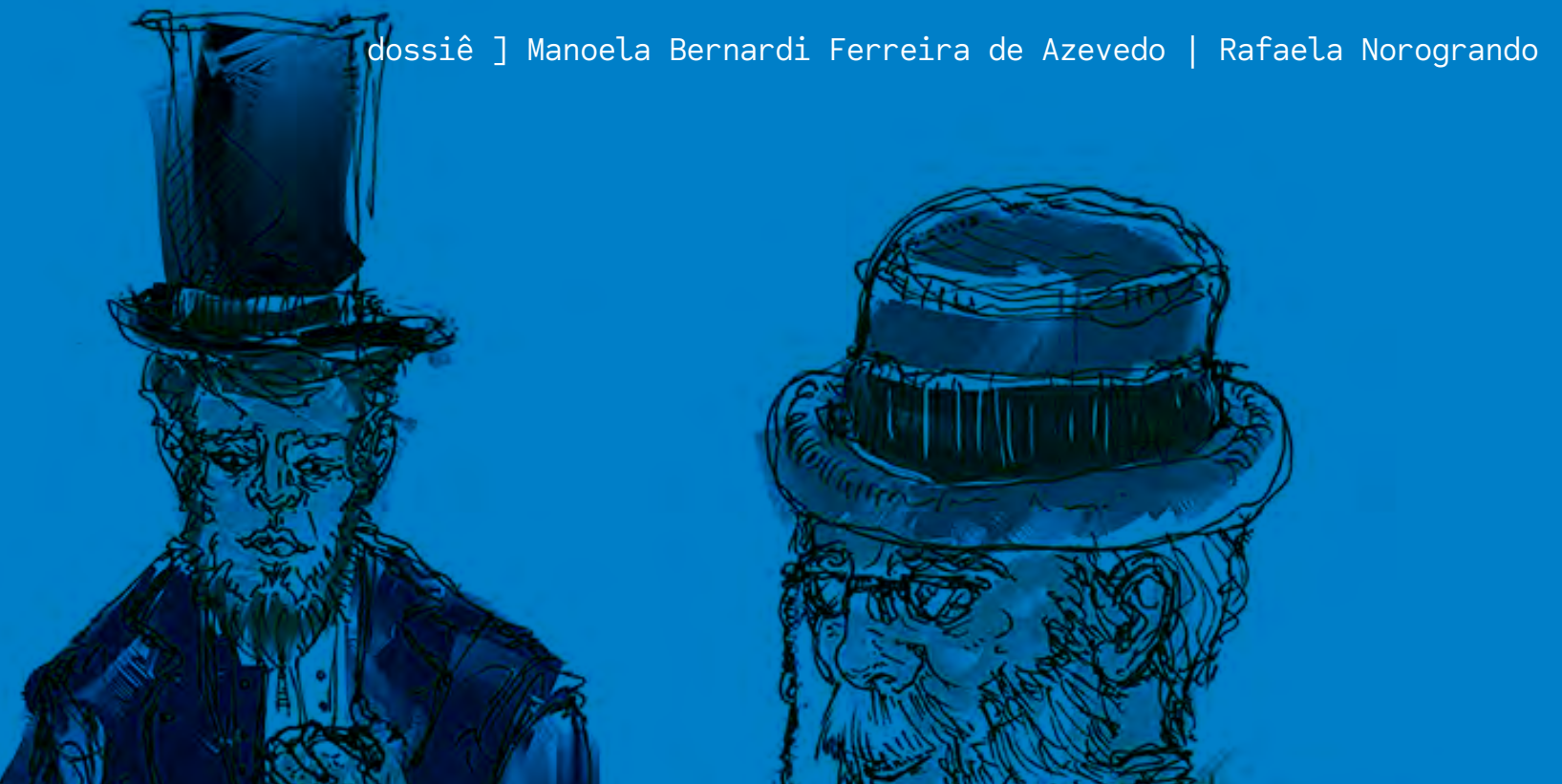

\title{
A literatura de cordel como meio de divulgação da moda na Portugal do século XVIII.
}

Cordel Literature ${ }^{1}$ as a means of spreading fashion in the $18^{\text {th }}$ century in Portugal
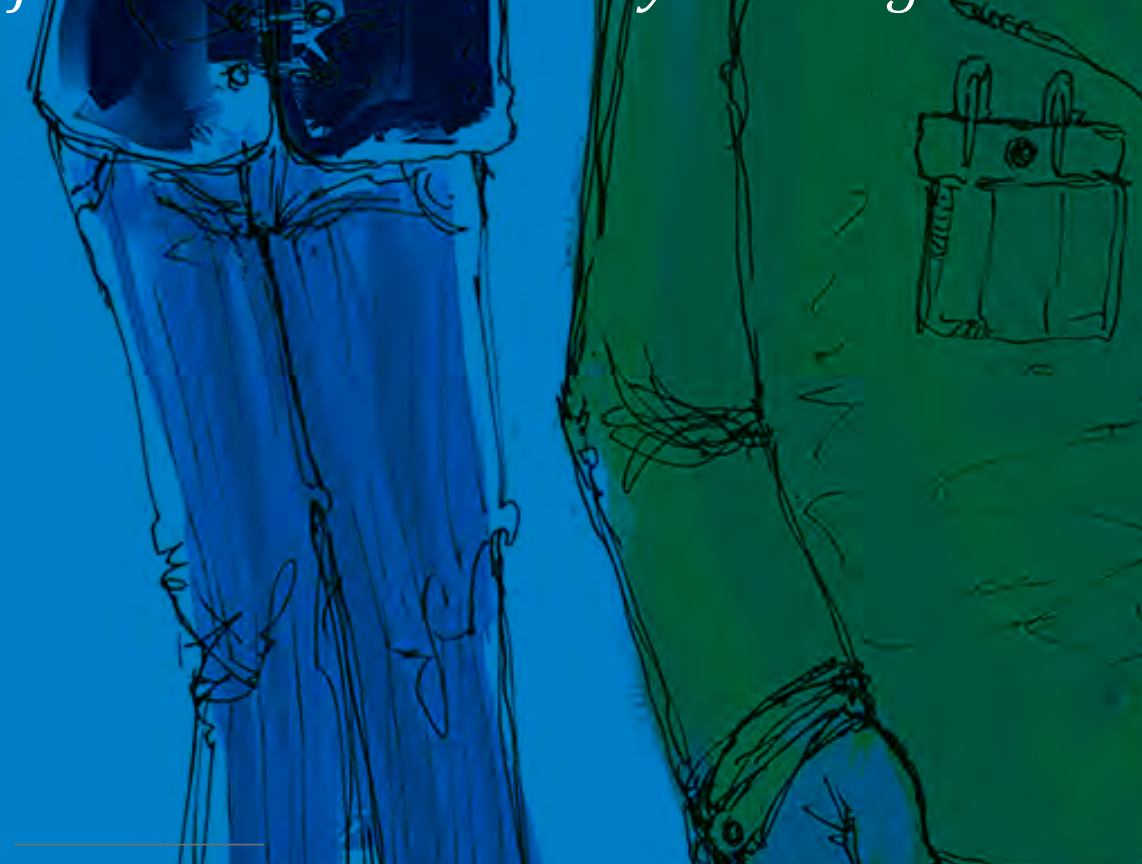

${ }^{1}$ Cordel Literature: a type of popular poem which is oral and printed in leaflets, generalzy-exposed for sales hanged on a string. 
Manoela Bernardi Ferreira de Azevedo²

ORCID: https://orcid.org/0000-0002-6998-3143

\section{Rafaela Norogrando 3}

ORCID: https://orcid.org/0000-0001-9813-4944

[resumo] Inúmeros fatos eclodiram e representaram a tomada de novas posturas e de pensamentos durante o século XVIII. Na Europa, as portuguesas setecentistas sentiriam e até participariam, ainda que timidamente, das tais transformações que decorreram no período denominado como Século das Luzes. Durante essa época, Portugal tinha como aliada a Inglaterra, mas também recebia fortes influências da França, sobretudo nas maneiras do vestir. Por meio de análise bibliográfica, principalmente de autores como Moura, Santos e Chantal, o presente artigo relacionará moda e literatura de cordel, contribuindo para o avanço da história do traje e da moda na relação com a literatura ao compreender as mudanças sociais e estéticas sofridas em solo português por meio da imprensa de cordel. Esses papéis volantes, como condutores das transformações sociais, culturais e, principalmente, estéticas em Portugal, permitirão-nos averiguar um pouco o dia a dia das portuguesas aristocratas e como o traje e a moda inglesa e a francesa foram recebidas e difundidas no continente lusitano.

\section{[palavras-chave] Estética. Vestuário. Mulheres. Papel volante. Sociabilidades.}

[abstract] A variety of emerging factors represented the adoption of new attitudes and thoughts during the $18^{\text {th }}$ century. In Europe, Portuguese women would feel and participate, even if not so expressively, on the renowned transformations that happened in the period known as the Age of Enlightenment. In that time, Portugal had England as an ally but also received strong influence from France, mainly on the way of dressing. Through a bibliographic analysis mainly from authors such as Moura, Santos, and Chantal, the present article will connect fashion and cordel literature, thus contributing to advancements in the history of clothing and fashion and their connections with literature. This will be done by understanding the social and aesthetic changes in the Portuguese territory through the cordel press. These cordel leaflets (also called "papéis volantes"), being conductors of social, cultural and mainly aesthetic transformations in Portugal, will enable an investigation about the aristocratic Portuguese women daily life, and also regarding how English and French clothing and fashion will be received and spread through the Lusitanian continent.

[keywords] Aesthetic. Clothing. Women. Cordel leaflet (Papel volante). Sociabilities.

Recebido em: 14-10-2019

Aprovado em: 05-12-2019

\footnotetext{
2 Mestre em Design de Moda pela Universidade da Beira Interior, Portugal. manoelabferreira@hotmail. com. http://lattes.cnpq.br/7897065013719070.

3 Doutora em Design pela Universidade de Aveiro, Portugal. norogrando@gmail.com. http://lattes. cnpq.br/8511467327323125.
} 


\title{
Introdução
}

Nos anos setecentos, múltiplos acontecimentos decorreram no continente europeu, muitos notadamente inspirados pela corrente filosófica Iluminista. Esse novo pensamento também motivou várias mudanças no campo da moda e do vestuário das damas portuguesas, como Santos declara:

\begin{abstract}
Vivia-se, na segunda metade do século XVIII, uma época marcada pela mudança, pela progressiva ascensão económica e social da burguesia, pelo surgimento de uma nova sensibilidade e novos gostos o que, forçosamente, deixaria marcas nas atitudes e comportamentos dos diversos grupos sociais. As Modas serão um dos indicadores dessas mudanças, provocando curiosas reações de imitação, usurpação e rejeição, que os textos irão reflectir magnificamente. (SANTOS, 2013, p. 139)
\end{abstract}

Ao analisar a moda, não se deve evidenciar somente o ramo do vestuário. Moda também se trata de expressões, vivências, comportamentos, etiquetas, sentimentos e emoções, até mesmo de aspirações e ambições humanas. A moda provoca uma identificação do sujeito com a sociedade e se comunica por sua estética, por intenções pessoais e expressões públicas ou, ainda, por seus ideais culturais, sociais, econômicos e mesmo políticos. Dessa maneira, assume-se moda como um fenômeno social.

As mulheres do século XVIII, principalmente as francesas, começaram a adotar uma nova postura. Mais ativas e participativas quanto às questões da esfera pública, fizeram do campo da moda sua forma de expressão. Passaram a se vestir de maneira "inédita", sugerindo também transformações no âmbito privado, mas, principalmente, na esfera pública. As portuguesas, que se espelhavam na estética francesa, levaram e implementaram em seus trajes essa nova mentalidade oriunda da filosofia iluminista, ainda que movidas pela exaltação do parecer e não do ser ${ }^{4}$.

Por outra percepção, a abertura do espaço público permitiu que o século XVIII fosse responsável por fazer surgir e difundir muitos textos sobre os trajes e a moda, "quer pelas publicações objetivas que lhe iam dizendo respeito, em França, quer pelos panfletos, ou literatura de cordel" (MOURA, 2010, p. 62). De maneira alternativa, a literatura de cordel ganha popularidade e notoriedade, expandindo essas novas maneiras do vestir que vinham dos países vizinhos: da aliada Inglaterra e, sobretudo, da França, país de grande prestígio. Em Portugal, tais publicações mostraram-se como importante ferramenta para a circulação e a difusão das novidades estéticas oriundas do estrangeiro visto que esse tipo de conhecimento estava limitado por "algumas críticas religiosas e raras descrições de acontecimentos reais ou crónicas cortesãs” (MOURA, 2010, p. 62).

\footnotetext{
${ }^{4}$ Ainda que as portuguesas não tivessem sido ativas quanto à sua participação social, política e econômica, tal como as senhoras francesas, seus trajes expressavam indiretamente essas transformações que o Iluminismo conduzia na sociedade francesa e, também por causa disso, foram muito visadas e criticadas pelos portugueses mais conservadores de setecentos.
} 
Contudo, esses folhetos não eram destinados somente a publicar os novos trajes que ganhavam fama na Península Ibérica. Outra grande finalidade, muito usada pelos lusitanos mais conservadores, era orientar, advertir, criticar e até censurar o uso dessas modas a fim de manter e perdurar a organização social e política do país.

Neste artigo, evidencia-se como a moda criou um paralelo com a literatura de cordel e como esse meio configurou e retratou as transições e as modificações da aparência feminina palatina da Portugal do século XVIII.

A literatura de cordel foi a base para este processo investigativo, tornando-se meio de análise das questões referentes ao vestuário. Os "papéis volantes", como também era conhecida, expõem o olhar dos sujeitos que os escreveram em função do que ocorria no contexto de setecentos, objetivamente tratando-se dos trajes e das modas que as portuguesas vestiam. Enquanto a imprensa jornalística ainda não se desenvolvia, esses panfletos foram cruciais para a difusão do saber comum e propriamente estético. São relatos detalhados que enriquecem a história, não somente a de Portugal, como também a de suas colônias, principalmente a brasileira.

Os cordéis utilizados neste artigo fazem parte da coleção da Biblioteca Pública Municipal do Porto, todos da segunda metade do século XVIII, retirados do trabalho de Moura, visto a impossibilidade de acesso. Como apoio para as pesquisas bibliográficas e para as fontes primárias, além de Moura, autores como Chantal, Santos e Nogueira engrandeceram o desenvolvimento da problemática aqui sugerida.

A definição do tema do presente artigo trata-se de um recorte do trabalho de investigação realizado em Portugal: para desenvolver a problemática da pesquisa de mestrado, pautada na questão "Como a aparência das mulheres portuguesas foi influenciada e dominada por França e Inglaterra e quais foram as consequências expressas no âmbito social, por meio da moda", durante o período de 1789 a 1807, a autora transitou pela literatura de cordel, visto essa ferramenta descrever a condição social das senhoras e de como a moda atingiu e seduziu o seu imaginário à medida que os trajes tornavam-nas mais evidentes e detentoras de certo poder na esfera pública.

\section{A literatura de cordel e a difusão da moda em Portugal}

No século XVIII, Portugal experimentou muitas mudanças em várias áreas do desenvolvimento social e cultural, além dos inúmeros acontecimentos de cunho político-econômico decorridos. Desde o século anterior, a principal origem dessas transformações tem relação com o avanço das novas vertentes filosóficas de cunho racionalista.

O Iluminismo fundamentou e impulsionou uma grande metamorfose por todo o continente europeu. A transformação deu-se não só nas vias culturais, sociais, políticas e econômicas, mas, principalmente, incentivou mudanças no pensar dos sujeitos que, claramente, foram percebidas nas formas diferentes de trajar, como será tratado no interior da sociedade palatina 
lusitana da segunda metade do século XVIII ${ }^{5}$. Para melhor compreensão desse contexto, é essencial fazermos uma breve imersão na história daquele período.

Dom João V havia se tornado o primeiro monarca dos anos setecentos. Coroado em 1706, em virtude de embates políticos ${ }^{6}$, ele manteria sua posição imparcial relativa às alianças políticas-econômicas. Voltando-se para as questões internas, o momento era oportuno para levantar a economia do seu país com as riquezas levadas do Brasil e fomentar a manufatura que chegava da Inglaterra, graças ao Tratado de Methuen ${ }^{7}$ acordado anos antes da sua aclamação, em 1703. No entanto, no seu íntimo, o rei possuía outras ambições para o seu governo. Seu foco e seu interesse estavam nas aparências que a sua corte exibiria. Opulência, ostentação, suntuosidade, magnitude, enfim, tornar-se-iam as definições mais corretas para o reinado de D. João V.

No ano da sua morte, em 1750, D. José I assume o trono e inicia sua gestão juntamente com o célebre Marques de Pombal, implementando políticas reformistas voltadas à reconstrução econômica do país. Os gastos exorbitantes do governo anterior forçaram o novo monarca a realizar uma série de medidas protecionistas e de desenvolvimento econômico com foco na produção nacional ${ }^{8}$.

Pombal foi embaixador no exterior, conviveu e assimilou os ideais iluministas e, como ministro, passou a endossar seus programas político-econômicos a partir dessa abordagem. Assim, ele pode ser considerado peça-chave na reformulação de Portugal, principalmente após a catástrofe de 1755 .

A filosofia das Luzes expandia-se voluntariamente pelo país e foi determinante para o surgimento de um "novo" português ${ }^{9}$. Os indivíduos despertaram para a busca do belo, para o desejo do que era novo, evidenciando a personalização por meio de uma maior liberdade de pensamento expressa por uma estética reformada.

\footnotetext{
5 Na segunda metade do século XVIII, o pensamento Iluminista inspirou o aparecimento do despotismo esclarecido por toda a Europa. Essa expressão foi usada para uma forma de governo que embora aprovasse a exaltação do Estado como mentor do poder soberano (Absolutismo), orientava-se pelos ideais de progresso, reforma e filantropia, oriundos do Iluminismo.

${ }^{6}$ Principalmente perante a Guerra de Sucessão Espanhola. Apesar de ser cobrado a tomar posição para se aliar com uma das potências, D. João V manterá a condução de seu governo na imparcialidade a fim de se envolver mais com o desenvolvimento interno.

Também conhecido como Tratado dos Panos e Vinhos, esse acordo foi feito entre Inglaterra e Portugal no ano de 1703. Promulgou uma troca, ainda que posteriormente fosse percebida como inviável para os portugueses, que estes forneceriam exclusivamente seu vinho aos ingleses, enquanto permitiriam a entrada de diversas manufaturas da Inglaterra, principalmente os têxteis.

${ }^{8}$ A Real Fábrica das Sedas, criada em 1734, foi fundamental para manter em vigor o caráter protecionista da política vigente do governo de D. José I. No intuito de fazer crescer a manufatura nacional de rendas e demais itens de moda, em 1751, promulga-se uma Pragmática contra o Luxo, a qual proibia o uso de têxteis e adornos estrangeiros (MOURA, 2010, p. 44).

Ainda que a política interna de Portugal não consentisse ideais iluministas, assim como Pombal, muitos outros sujeitos foram responsáveis por inserir e fortalecer tais propostas em solo português. É o caso, por exemplo, dos imigrantes franceses, emigrantes estrangeirados (comerciantes, marinheiros, "cabeleireiros, livreiros, negociantes, mercadores, alfaiates, pintores, militares, nobres e clérigos"), intelectuais, filósofos, maçons, diplomatas, viajantes e alguns burgueses (RAMOS, 1988, p. 147 citado por FERREIRA, 2018, p. 78).
} 
Fazia-se imprescindível a adoção de uma aparência que se desvencilhasse do antigo e tradicionalista, de tudo que se relacionasse com o passado. Seguindo esse caminho, a aristocracia, detentora das preferências e do poder hierárquico, estava ávida por uma moda que fizesse sentido a esses novos tempos, como nos indica a seguinte pronúncia de uma amante da moda portuguesa: "Ai não se fassa rabujento, deixe-se dessas portuguezadas antigas que já estamos em outro século"10.

Quanto à nova estética lusitana, as novidades da moda eram ditadas pela França e adentraram em Portugal por muitos meios, como jornais, livros, folhetos e, sobretudo, pela literatura de cordel:

[...] foi o século XVIII o grande gerador e difusor dos textos sobre moda, quer pelas publicações objectivas que lhe iam dizendo respeito, em França, quer pelos panfletos, ou literatura de cordel, que também em Portugal, se mostrariam como grande passo alternativo no que toca à informação sobre trajes e modas, que até então estaria confinada a algumas criticas religiosas e raras descrições de acontecimentos reais ou crónicas cortesãs. (MOURA, 2010, p. 62)

Os papéis volantes ${ }^{11}$ popularizaram-se ao mesmo tempo que houve o despertar da aceleração da imprensa, ampliando o território cultural e sendo também responsável pela transmissão da literatura (NOGUEIRA, 2003, p. 22-24). Tornara-se tão comum que, entre as décadas de 1770 e 1790, a literatura de cordel penetrava em todas as camadas sociais, inclusive a burguesa, que paralelamente ascendia (SANTOS, 2013). Esse tipo de escrita:

[...] pactuava com facilidades de acesso para um público mais vasto, quer pelo preço baixo, como pela variedade de locais de venda, ou pela acessibilidade da escrita, mais simples e proposta em diversidade de temas e estilos. Isso permitiria que agradasse a um público de diversos estratos sociais, desde os mais nobres, em reacções de diversão, encanto ou rejeição; burguesia ascendente, marcada já por atitudes e comportamentos, decorrentes de uma nova sensibilidade e gostos e apta a usurpações ou imitações moderadas; como aos mais analfabetos, pela simplicidade da escrita e possibilidade de fácil transmissão oral. Ora isto é mais do que suficiente para vincar a importância dos folhetos de cordel para a nossa história cultural e social, nomeadamente na reconstrução do panorama das modas, no nosso país, embora não se esgotando aí o seu rico contributo. (MOURA, 2010, p. 63)

\footnotetext{
${ }^{10}$ Novo entremez intitulado $A$ receita de ser peralta ou de casquilharia por força (Lisboa: 1789, p. 10 citado por MOURA, 2010, p. 15).

${ }^{11} \mathrm{~A}$ literatura de cordel também recebia esse nome, assim como folhetos volantes e cordéis.
} 
Como ressaltou Moura, a grande massa popular portuguesa de setecentos era uma importante apreciadora desses textos. Seja pela escrita simples e fácil ou pela oratória, os cordéis agradavam cada vez mais os vários estratos sociais. Em versinhos, entremezes, sátiras ou poemas, simples ou eruditos, foram muito bem aceitos pelos analfabetos. Por causa de a literatura de cordel ser teatralizada, ou simplesmente da audição de leituras em voz alta, os sujeitos mais simples, humildes e menos exigentes puderam ter contato com a cultura escrita, o que possibilitou seu acesso às novidades que circulavam em Portugal (NOGUEIRA, 2003).

Moura (2010) ainda sugere que tanto burgueses quanto aristocratas, até mesmo o próprio rei, entretinham-se com esses papéis por meio das dramaturgias que faziam em suas casas como atividade de celebração ou passatempo. Essa situação pode assemelhar-se em muito aos típicos "salões" que, na França, eram habituais na aristocracia. Tal costume também era praticado em Portugal de setecentos.

Um dos principais fatores que fez os cordéis serem acolhidos pela população lusófona, ainda que uns com maior sucesso do que outros, está no fato de que essas obras eram economicamente acessíveis. Não só por utilizarem material precário, mas também tinham uma "má impressão, uma deficiente tintagem e uma grosseira composição" (SANTOS, 1989, p. 137).

\footnotetext{
O preço dessas publicações também era mais baixo do que o dos livros comuns, quase inacessíveis à maior parte da população. Assim como o aumento do número de letrados também se apresentava como elemento coadjuvante a este panorama. A isto juntamos, ainda, o facto de se distinguirem vários locais de venda, uma vez que, no século XVIII havia ainda mais tipografias e, que até as reais se dedicavam à produção de folhetos de cordel. E assim, tudo convergia para que os folhetos de cordel atingissem um público vasto e de diversos estratos sociais, mesmo dos mais analfabetos. (MOURA, 2010, p. 68)
}

Os cordéis eram comercializados por vendedores (ou papelistas) que, geralmente, eram homens cegos que recebiam apoio e preferências concedidas pelo rei (SANTOS, 2013). Ainda havia "os impressores aspirantes a livreiros; os "volanteiros", que vendiam porta a porta e praticavam preços competitivos; os livreiros e alguns comerciantes, em loja aberta" (MOURA, 2010, p. 75), também praticavam esse ofício. Os que eram ambulantes ou não tinham estabelecimento físico vendiam os cordéis da seguinte maneira:

\footnotetext{
Ora, por literatura de cordel entender-se-á, então, o imenso e diverso conjunto de textos que se destinavam a ser dependurados em cordéis suportados por preguinhos ou alfinetes, em paredes de madeira ou a circular pendentes de vendedores ambulantes, para que expostos ao público o pudessem aliciar à compra. (MOURA, 2010, p. 66)
} 
Os papéis volantes também receberam influências dos países vizinhos. Santos (2013) aborda que muitos dos folhetos que circulavam em Portugal eram traduções ou adaptações dos textos espanhóis. Alguns, inclusive, chegavam e eram comercializados na língua de origem.

Havia ainda folhetos em que os autores assinavam suas obras e outros que preferiam ficar no anonimato. Aqueles que optavam por se expor possuíam certa "intervenção normativa" no conteúdo por causa dos interesses da Igreja e do Estado em propagar um discurso "oficial", ou seja, de cunho pedagógico e crítico ${ }^{12}$ quanto aos gastos em modas e luxos, assim como na repreensão do consumo exagerado. Um recorte do texto de cordel traduz claramente essa intenção: “Ah, luxo causador de eterno dano/ Do riquíssimo Império Lusitano!/ Tu podes converter em vil pobreza,/ Com tua perversão, tanta grandeza"13.

O maior interesse desses escritores era conseguir o aval de impressão das autoridades censórias (SANTOS, 2013, p. 140). Por outro lado, os que optaram pela escrita anôni$\mathrm{ma}^{14}$, clandestina, tinham a possibilidade de escrever sobre diversos assuntos e fatos sem estarem submissos a preceitos e diretrizes.

$\mathrm{Na}$ análise de Santos (2013), frequentemente nos textos de cordéis percebe-se o discurso das Sagradas Escrituras para reprovar as "profanidades" da moda e do luxo, bem como para contrabalancear os exageros. Essa dissonância estava no fato de que as "modas que os portugueses affectao demaziadamente, e as mulheres ainda mais fazem um luxo diabólico, que destroí as casas, consome o dinheiro que era para sustento delas, e emfim, faz uma dezordem"15.

Outro cordel faz a seguinte declaração:

Vivão Senhoras conforme as suas rendas (...) deixem os enfeites, e o luxo, vivão com mais moderação (...) ponhão as suas esperanças só no Ceo, [...] porque só a glória do Ceo he que dura para sempre, as pompas e dignidades do mundo nada valem.... ${ }^{16}$

\footnotetext{
${ }^{12} 0$ "objectivo da Igreja e do Estado seria exigir a decência dos textos, embora permitissem, por vezes, algumas abordagens menos ortodoxas, desde que com intenção moralizadora ou pedagógica” (MOURA, 2010, p. 67).

${ }^{13}$ Queixas de Clorindo ou reprhençam amigável das modas extravagantes (Lisboa: Oficina de Domingos Gonsalves, 1782 citado MOURA, 2010, p. 58 (anexos)).

${ }^{14} 0$ anonimato permitia ao escritor, principalmente, escrever textos que a censura desaprovava. Logo, a disseminação desses cordéis não colocaria em risco a segurança do autor audacioso. Tais publicações foram conhecidas como "folhetada incómoda" (NOGUEIRA, 2003, p. 8. citado por MOURA, 2010, p. 68).

${ }^{15}$ Novo entremez intitulado $A$ receita de ser peralta ou de casquilharia por força (Lisboa: 1789, p. 2 citado por MOURA, 2010, p. 79).

${ }^{16}$ Relação de huma carta escrita às Peraltas em a qual se The apontam os rediculos trastes de que usão... (Lisboa: Officina de Francisco Borges de Sousa, 1787, p. 13 citado por SANTOS, 2013, p. 141).
} 
Logo, visto desembolsarem enormes valores que deveriam ser doados à igreja, os gastos desnecessários eram considerados pecado. Além disso, com o crescimento da burguesia enriquecida, sendo esta capaz de gastar tantas quantias em dinheiro quanto os aristocratas da corte, percebia-se que certos símbolos de poder estavam sendo usurpados ao ponto de desorganizar a hierarquia social. Nesse sentido, em 1749 , foi instaurado um protocolo e leis contra o luxo a fim de que cada indivíduo andasse conforme seu status (MOURA, 2010). 0 intuito era garantir a estabilidade social, evitar gastos excessivos e criticar a ostentação usurpadora. Assim descreve uma personagem de cordel:

\section{“A pragmática já me não espanta,/ Antes já me parece boa, e santa,/ Porque a todos acode/ A não gastar ninguém mais do que pode:/ E já com ella as Franças Portuguezas/ Não fazem a seus pays tantas despezas [...]/ Assim fica sendo a tal pragmática/ Remédio prodigioso/ Para evitar este mal contagioso"17,}

Entre os variados conteúdos possíveis de ser tratados na literatura de cordel, o que tinha maior popularidade e prestígio incluía falar sobre as modas, masculina, mas, principalmente, a feminina (SANTOS, 2013). A moda foi considerada um tema de grande estima para os portugueses, pois, no decorrer dos "séculos XVI e XVII a inexistência das revistas de moda ou dos catálogos de loja levava a que a divulgação do traje estivesse confinada às fontes documentais e gráficas existentes" (DUARTE ${ }^{18}, 2004$, p. 13 citada por MOURA, 2010, p. 76).

Na prática, informações e referências sobre moda estrangeira eram muito difíceis e raras em terras lusitanas. Além dos escassos periódicos franceses que ali desembarcavam, muitas senhoras da corte ansiavam pela chegada das pandoras para se informar acerca dos novos modelos de vestuário. Eram pequenas bonecas de porcelana, comercializadas por todo o continente, com a função de representar, em tamanho miniatura, as últimas modas que as francesas vestiam em Paris. Em 1739, a princesa Maria Vitória ${ }^{19}$, esposa de D. José I, escreveu para a sua mãe, a rainha da Espanha, para que lhe enviasse duas bonecas, pois sua sogra, a rainha Maria Ana da Áustria e esposa de D. João V, negava-se a lhe mostrar as três bonecas recém-chegadas da França, vestidas e penteadas à moda (SANTOS, 2013).

Sendo assim, os folhetos de cordéis foram inovadores e os maiores responsáveis por divulgar e trazer notícias das modas usadas nas cortes dos países vizinhos: "As referências espalhavam-se por muitos folhetos, espelhadas na preocupação das personagens em "seguirem a moda" para trajarem à moderna" (MOURA, 2010, p. 77).

\footnotetext{
${ }^{17}$ Testamento e ultima disposição que de seus ornatos, enfeites, e adornos fez huma França, por causa da nova pragmática, querendo reformarse, deixar o mundo, e entrar em religião, repartindo primeiro pelos conventos pobres as suas melhores gallas, e fazendo outras obras pias, como nelle pode ver o fleumático leitor (Catalunha: Emprensa de Francisco Guevarz, 1751, p. 4 citado por MOURA, 2010, p. 87-88)

${ }^{18}$ DUARTE, Cristina L. Moda. Lisboa: Quimera Editores Ltda., 2004.

${ }^{19} \mathrm{Em}$ algumas bibliografias, a esposa de D. José I também era reconhecida como D. Mariana Vitória de Bourbon.
} 
Consequentemente, as mulheres tornam-se protagonistas da moda e dos textos de cordel, ainda que a sua grande maioria ocupando papéis de transgressoras da sociedade graças à "ousadia dos seus trajes, pelos seus gastos excessivos, pela bizarria dos adornos, num rol quase infindável de acusações” (SANTOS, 2013, p. 151).

Póde haver em todo o Mundo que se compare a mim? Tudo nesta caza são modas, tudo são poupas, tudo choroens, plumas volantes, e por fim mil traquinadas, que sendo as loucas de minhas filhas, e mulher quem as põem na cabeça, a minha he que fica doida ${ }^{20}$.

Nesse contexto, em que a moda valorizava o feminino e sua beleza, ela também contribuiu às questões do casamento. Como esclarece Santos (2013), as roupas só eram condenáveis quando ultrapassavam os limites da decência e dos bons costumes. Mas, para expor a condição ou o status hierárquico legítimo, os adornos e a moda eram permitidos. Inclusive, era um direito reconhecido que as damas podiam e deviam desfrutar principalmente para conseguir ou agradar um marido e, assim, expor a honra e o poder do cônjuge por meio do seu vestuário, até porque não poderiam "privar sua mulher ou filha de se apresentarem com a decência própria da sua condição" (SANTOS, 2013, p. 152).

Havia grande intenção de que a maioria das publicações dos folhetos tratasse de assuntos dedicados à sociedade, ao gosto, ao casamento, além de conter instruções dirigidas aos pais sobre a forma de educar e orientar seus filhos, tornando-os virtuosos e úteis, honrando a pátria e a família (SANTOS, 2013).

Um folheto bem lembra que "o primeiro dote da Mulher para o mundo he a formosura, e esta he a Prerogativa com que se elevam. Os Homens se fazem estimar pelo valor, as Mulheres pela formosura"21. Porém, quando isentas de graça e beleza, a aparência de moda criava desilusões, como desabafa o noivo:

Eu vi certo marido lamentando/ Os enganos que teve (...)/ He possível, dizia este bom homem,/ Que eu casasse com as modas,/ Que buscando mulher, nestes instantes/ Não ache mais que fitas e volantes? / Que visse huma mulher fazendo vulto,/ Anafada e vistosa,/ Que depois de casar, neste conflito,/ Em lugar de mulher ache um palito?/ Por este modo o triste se queixava,/ Como espelho dos outros:/ Ninguém busque casar sem mais exames/ C'uma mulher armada por arames ${ }^{22}$.

\footnotetext{
${ }^{20}$ Os Peraltas Castigados... (Lisboa: Officina de Domingos Gonsalves, 1786, p. 1 citado SANTOS, 2013, p. 152).

${ }^{21}$ Compendio de Theologia Moral Evangelica... (Lisboa: Regia Officina Typografica, 1776, p. 53 citado por SANTOS, 2013 p. 159)

${ }_{22}^{2}$ Modas do Tempo Descubertas na Quarta parte dos Opios (Lisboa: Officina de Simão Thaddeo Ferreira, 1788 , p. 5 citado por SANTOS, 2013, p. 160).
} 
Tal discurso também demonstra certa moralidade - uma vez que propõe a relação da estética com a honra e a dignidade pessoal -, e uma crescente valorização social do papel atribuído à mulher. Trata-se do direito de reconhecimento social e da honra que as senhoras disputam por meio da imagem que transmitem (SANTOS, 2013). Por isso, a moda provocava o princípio de progresso e conquistas às damas, ainda que, paralelamente, sofressem julgamentos e difamações.

Em Portugal, os cordéis também foram uma ferramenta muito útil para dar voz às figuras femininas. Estamos ainda diante de uma conjuntura extremamente patriarcal. Portugal sempre foi uma sociedade muito conservadora e católica, o que implica dizer que defendia a figura da mulher como mãe e dona do lar. Elas deveriam desempenhar seus trabalhos em prol da sua família, em um convívio estritamente privado. Nada, nenhum assunto que fosse público, poderia ser dialogado ou discutido com uma mulher. A educação que recebiam era para se aperfeiçoarem como mães, donas do lar e boas esposas.

Inclusive, Moura elucida que o vestuário também teve a finalidade de categorizar as mulheres socialmente ao alegar que, nas roupas, a "funcionalidade se impõe também à moda" (MOURA, 2010, p. 25). Ao se referir às ancas, a autora diz:

\footnotetext{
Se não repare-se que, no século estudado nos deparamos com um alargamento significativo no que toca às ancas da silhueta feminina, em termos de vestuário, o que longe de ser prático, representa a sua "função" de gestação e subliminarmente um estatismo que seria propício por ser natural à mulher. Seria pois a opressão e a compressão de contornos adequada e natural à mulher de então? 0 certo é que era forçada a muito do que se lhe tornava posteriormente "natural". (MOURA, 2010, p. 25)
}

Tratando-se das referências de moda que influenciaram Portugal desde o governo de D. João V, Inglaterra e França foram os dois principais países que ditaram as novas aparências. Para além de fatores político-econômicos, ambos serão os responsáveis por difundir seus modos e, claro, suas modas em solo lusitano.

A moda em Portugal não seguia uma estética própria. Os símbolos de poder, elegância e suntuosidade que Luís XIV instaurou na França, no começo de setecentos, serviram de inspiração ao monarca português (CHANTAL, 1970). A corte de Versalhes era muito prestigiada pelo rei D. João $V$, que introduziria tal gosto exacerbado da cultura francesa na corte lusitana. E com as riquezas advindas da colônia brasileira era possível para o monarca manter uma política externa de afirmação do prestígio e do poder da coroa, envolvendo e paramentando sua corte de fausto, requinte e ostentação. Isto facilitou e permitiu a entrada de muitos costumes franceses em Portugal e, obviamente, de uma moda à francesa.

As novidades vinham do estrangeiro e disseminavam-se pelo interior da corte, centro irradiador e fonte do que era considerado referência de modo, como declara Santos: "Trajar bem é agora sinónimo de vestir à moda, moda que vem do estrangeiro e de que são os primeiros consumidores os membros dos grupos sociais elevados" (SANTOS, 2013, p. 144). 
Sendo assim, era importante esse contato com a aristocracia, tanto que na torina do frei Lucas de Santa Catarina, sugere-se que as senhoras tivessem "hua amiga no Paço para a enformar das modas, pois de lá hé que saem todas as invenções de toda a legitima moda" (RODRIGUES, 1983, p. 160 citado por SANTOS, 2013, p. 144).

A forte veneração a tudo que se dizia oriundo da França fez com que Portugal muito se assemelhasse à aparência dita como moda estrangeira. Isto implica dizer que as portuguesas da corte, a classe que mais possuía contato com as novidades regressas em solo lusitano, fossem as primeiras a ostentar a aparência francesinha ${ }^{23}$. Essa estética se manterá nos reinados seguintes, na segunda metade do século XVIII.

D. José I, ainda que a contragosto, preservou certa tendência aos gastos a fim de se espelhar na pompa da sociedade francesa, permitindo que essa cultura e essa estética adentrassem, e até se antepusessem, à cultura lusófona. Em virtude de os portugueses interessarem-se mais pelos artigos estrangeiros do que pelos produtos locais ${ }^{24}$, desprezavam as fábricas nacionais e ambicionavam os artigos trazidos por contrabandistas ${ }^{25}$. Para eles, nada "importava à elegante frívola, apaixonada pelas modas francesas, ou ao fidalgo amador de caixas de música, que talvez bastassem dez anos de esforços e paciência para obter no seu país artigos aceitáveis" (CHANTAL, 1970, p. 24).

Tal atitude foi amplamente criticada por alguns autores de folhetos de cordel. Em um deles, afirma-se que os estrangeiros regressos “sabem que em Portugal há louca gente,/ Que o luxo reina agora, o que he patente,/ Carregam seus paquetes, e vem logo/ Com dez mil bugigangas fazer jogo;/ E lhe corre o dinheiro como hum rio,/ E nisto Portugal fica vazio (...)"26.

Para os defensores dessa estética, pretextos políticos e econômicos conduziram e sustentaram as razões para essas modas. Entre algumas vantagens, o cordel expõe a opinião de alguns sujeitos, no fim do século:

\footnotetext{
23 "Os depositários da moda sempre foram, sobretudo, as classes mais elevadas, já que, entre o povo a moda se mantinha durante longos períodos de tempo e, quando acontecia uma mudança, era apenas uma leve mudança de estilo" (MOURA, 2010, p. 30-31).

24 Entre alguns motivos, por serem caros e de pior qualidade.

${ }^{25} \mathrm{Um}$ fato interessante pode exemplificar essa escolha. Passado o terremoto, "no dia seguinte ao da catástrofe de 1755, Lisboa, sem pão nem tecto, estava também sem vestuário. Os sobreviventes só possuíam o fato que traziam no corpo, de um modo geral roto, queimado ou sujo" (CHANTAL, 1970, p. 210). Sem poder escolher, a população e muitos da corte portuguesa tiveram que usar bureal castanho para se vestir e para se proteger do frio e da chuva. Tempos depois, o rei e a rainha ainda se encontravam nessa condição precária. O desejo por retornar ao luxo e à vaidade fez despertar uma disputa pelos produtos de luxo que "entravam em Portugal de contrabando e atingiam preços aterrorizadores" (CHANTAL, 1970, p. 210). Inconsequentemente, incentivaram o contrabando de produtos internacionais ilícitos.

26 Queixas de Clorindo ou reprhençam amigável das modas extravagantes (Lisboa: Oficina de Domingos Gonsalves, 1782, p. 3 citado por MOURA, 2010, p. 43-44).
} 
Eu a moda defendo: que o dinheiro assim corre; desfruta o sapateiro, o alfayate, lucra o mercador, o seringueiro, o sujo penteador, os gêneros, se extrahem, e na verdade, nisto consiste hum bem da sociedade ${ }^{27}$.

Assim sendo, durante praticamente todo o século XVIII, os trajes que seriam usados e propagados em solo lusitano tinham uma estética muito parecida, ou mesmo igual, à que era usada em Paris. Havia algumas poucas exceções para os que não eram a favor da moda francesa e seguiam uma aparência mais conservadora ${ }^{28}$, situação que se dava graças aos tecidos que vinham da Inglaterra em decorrência do acordo comercial com os ingleses ${ }^{29}$.

Como mencionado, uma considerável parcela populacional era contra a permissividade do monarca quanto à moda difundida e, por isso, temiam a entrada das ideias iluministas que vinham com alguns franceses imigrantes "estampadas" nesses trajes (FERREIRA, 2018). Esses conservadores, geralmente, conduziam suas alegações destacando os excessos dos trajes das senhoras que se expunham publicamente e como tal situação desequilibrava a harmonia social.

$\mathrm{Na}$ literatura de cordel, os personagens conservadores que frequentemente aparecem eram "o marido, o pai, o amigo velho, que defendem o antigo, o tradicional, por ser honesto, sério e digno, conseguindo convencer os filhos das suas opções na maioria das vezes, para que se cumprisse a intenção pedagógica" (MOURA, 2010, p. 78). É o caso deste cordel que expõe a voz do filho de um conservador:

Eu vou-me verificando no que diz meu pai, o certo he que as pessoas antigas como tem experiência fallao verdade em muitas cousas, os portugueses são excessivos nas modas e agora he que me vou dezenganando ${ }^{30}$.

Ainda que as mudanças consistissem em uma renovação das aparências, os ornamentos ainda eram tão exagerados que os mais conservadores reagiam mal a esses luxos, censurando-os, como expressado neste cordel:

[...] he verdade que abundao as criticas contra as Madamas [...] ellas tem sido a ruína, e o estrago de immensas famílias: o luxo tem prevertido a ordem das sociedades, pobres pais, que com seus mediocres lucros apenas podiao manter-se

\footnotetext{
${ }^{27}$ Satyras em louvor das Modas (Lisboa: 1783, p. 13 citado por SANTOS, 2013, p. 150).

28 "[...] os que mantinham as modas antigas, defendendo o vestuário do passado eram frequentemente apelidados de: "gingas", "góticos", "antiquários", "antigualha do tempo das adagas", amantes dos usos sebastianistas (Novo entremez intitulado $A$ receita de ser peralta ou de casquilharia por força. (Lisboa: 1789, p. 6; p. 11 citado por MOURA, 2010, p. 77). Também eram taxados com nomes muito específicos: "sécias", "peraltas", "casquilhos", "tafulas" (MOURA, 2010, p. 83).

${ }^{29}$ Diz respeito ao Tratado de Methuen, ou também, Tratado de Panos e Vinho.

${ }^{30}$ Novo entremez intitulado $A$ receita de ser peralta ou de casquilharia por força (Lisboa: 1789, p. 7 citado por MOURA, 2010, p. 78).
} 
no regaço da paz sem dividas, eu os vejo pobres, empenhados, e talvez faltos de credito para cevarem o gosto de suas filhas, e mulheres com as modas que de dia, em dia se inovao, e se descobrem: e que modas são estas? Seja-me permitido esta expressão: ridicularias que já mais se podem ver sem rizo, e sem escarneo $[\ldots]^{31}$.

Também os saudosistas reclamavam das mudanças que viam:

No nosso tempo não havia estes toucados mas havia mais dinheiro, não gastava huma senhora dous dias para armar hum castello na cabeça com huma turbamulta de trapalhada então comíamos os chouriços com ovos agora trazem nos V. m. no toutiço e pendurados pela cabeça ${ }^{32}$.

Para os apreciadores dos novos códigos de representação social, tratando-se das roupas, esses tradicionalistas eram muito antiquados e, por isso, criticados. Uma das personagens do folheto irritou-se com seu marido e disse: "Pois se V.M. quer ser gótico, se quer ser refructario ás leis da moda, eu o não quero ser [...] a culpa tive eu em cazar com hum homem rançoso, sem amar as modas amando a jarretisse [...] $]^{\prime 33}$. Contudo, era mais que necessário estar vestido à moda. Fazia parte de um contexto que demostrava vanguardismo, bom tom e poder. tendências,

Na opinião de Moura, sempre houve os que adoravam e os que abominavam as novas

[...] positivas ou negativas, sempre havia críticas. Mais tarde, criticar-se-iam, também, as novas modas, os vestidinhos estreitos, que transformavam o aspecto da mulher, dando-lhe formas mais esguias, tendências influenciadas pela adesão ao Traje Império. (MOURA, 2010, p. 84)

A partir da segunda metade de setecentos, as senhoras portuguesas vestiam-se com essa moda estrangeira que vinha de Paris. Na literatura de cordel, além das críticas ao luxo, às ostentações sem medidas e ao abandono dos portugueses aos valores tradicionais de sua cultura, havia uma ampla disseminação de folhetos que impiedosamente ridicularizavam esses tipos de trajes e as mulheres que o vestiam:

\footnotetext{
${ }^{31}$ Gracioza, e divertida farça ou o novo entremez intitulado $A$ defesa das madamas a favor das suas modas, em que deixao convencida a paraltisse dos homens (Lisboa: Oficina de António Gomes, 1742, p. 8 citado por MOURA, 2010, p. 22-23).

${ }^{32}$ Novo entremez intitulado $A$ receita de ser peralta ou de casquilharia por força (Lisboa, 1789, $p$. 10 citado por MOURA, 2010, p. 23).

${ }^{33} \mathrm{~A}$ grande dezordem que teve o Marido com a Mulher Por não querer que trouxesse o Tupete à Marrafe (Lisboa: Officina de António Gomes, 1791, p. 5 citado por SANTOS, 2013, p. 148).
} 
As madamas deste tempo são painéis de ridículas figuras: de que serve huma manta com pontas de cortina de caza de pasteleiro! De que serve hum tal toucado feito de tisse frizado todo posto em cocuruto com púcara de doce com seu papel escrespado $?^{34}$

A moda evoluiria do barroco do começo do século para o rococó, e deste para o neoclássico em fins de setecentos. Então, a partir da segunda metade do século e em poucas décadas, há mudanças bem visíveis nos trajes.

No início dos anos 1750, as anquinhas (ou "guarda-infantes", como também eram chamadas) ainda eram muito usadas pela sociedade palatina. Essas grandes armações com a finalidade de aumentar exageradamente o volume lateral das saias ganharam fama nos cordéis e receberam inúmeras críticas. Entre alguns exemplos, cita-se o deste autor anônimo:

As anquinhas da moda/ Não posso acomodar-me/ Que são estas senhoras, penso e acho/ Hum ópio da sentura para baixo/ Não há porta em que caiba huma senhora/ Não há sege em que caiba/ E a sala maior com esta idéa/ em tendi seis senhoras fica cheias ${ }^{35}$.

Por volta de 1770, as enormes anquinhas reduziriam de tamanho para se harmonizarem com os penteados, que vão ganhando destaque no figurino. Bem empoados e cheios de cachos, começaram a dar lugar para a aplicação de alguns adereços. Fitas e laçarotes embelezavam - ou não - as senhoras, como sugere o cordel: "Assim também graça infinita eu acho,/ Nas largas fitas pela testa abaixo;/ Mas quando o rosto he bello, à formozura/ Este adorno bastante a desfigura" 36 .

Principalmente no reinado de D. Maria, a moda parisiense dos toucados adentrará também no gosto das damas portuguesas. Essas peças utilizadas pelas francesas tinham um tamanho tão desproporcional que era praticamente impossível não ganharem inúmeras sátiras nos papéis volantes. 0 escritor Tolentino foi um dos escritores que mais ganhou fama ao descrever esses penteados. 0 cabelo das damas tinha "huma altura desmarcada de poupa e tão cheia de flores e fitas como huma laje de capella"37. Mas, apesar de ser um luxo que as damas aderiram, certamente eram muito incômodos, como descrito:

\footnotetext{
${ }^{34}$ Defeza das Madamas a favor das suas modas... (Lisboa: Officina de António Gomes, 1792, p. 9 citado por SANTOS, 2013, p. 148).

${ }^{35}$ Opio que dão os Homens e as Senhoras na cidade de Lisboa huns aos outros... (Lisboa: Officina de Simão Thaddeo Ferreira, 1786, p. 7 citado por SANTOS, 2013, p. 155).

${ }^{36}$ Queixas de Clorindo ou reprehençam amigável das modas extravagantes. (Lisboa: Oficina de Domingos Gonsalves, 1782, p. 14 citado por MOURA, 2010, p. 46).

${ }^{37}$ Queixas de Clorindo ou reprehençam amigável das modas extravagantes. (Lisboa: Oficina de Domingos Gonsalves, 1782, p. 14 citado por MOURA, 2010, p. 46).
} 
Também o amável sexo feminino, / Há muito grande excesso e desatino/ Nos enfeites de que usam, que igualmente/ Causam riso também à sábia gente. [...]/ O mandarem tirar as almofadas/ Das carroagens as que vão toucadas,/ Porque não vá tocar nos tozadilhos/ Já brancos da pomada, e dos polvilhos./ E porque não lhe basta esta cautélla,/ Obrigada se vê a Ninfa bela/ A contranger seu corpo delicado,/ Ou de levallo ali como esmagado. ${ }^{38}$

Também bastante usados, os chapéus passariam a ser grandes e muito adornados, cheios de flores e fitas conforme o relato do cordel: "Mas como hia contando: A tal francesa/ No exterior, em tótum, Portuguesa/ Vinha com tal chapéo, que foi preciso, /Que me abaixasse logo de improviso/ Para passar o tal senhor cometa,/ E que só a sombra me deixou pateta"39.

Os trajes, modelos de vestido redingote e "à húngara", eram consumidos entre as damas afrancesadas poucos anos antes. 0 último, especialmente, não era bem quisto pelos moralistas, pois a sécia coquette, da qual também a chamavam de "frança", "casquilha" ou então peralta deixava o corpo muito à mostra (MOURA, 2010). Nem mesmo os lenços, ainda que transparentes, conseguiam esconder "os seus decotes muito abertos, os braços descobertos, a garganta aconchegada no folho de rendas indiscretas, como no tempo em que ficava enclausurada ao abrigo das suas persianas de grades" (CHANTAL, 1970, p. 116). Pelo fato de esses vestidos seguirem as modas francesas da época, tendo decotes cada vez mais proeminentes, na percepção de Chantal, a peça era como se fosse "pagã, portanto até à cintura, mas ferozmente casta a partir daí a beldade [vivesse] o seu grande momento de garridice" (CHANTAL, 1970, p. 117).

Com a Revolução Francesa insurgida em 1789, o fim do Antigo Regime torna-se realidade na França. E Portugal, por seguir muito os costumes do país vizinho, também sentiu as mudanças políticas na sua sociedade. Inicialmente, o luxo da primeira metade do século transformava-se após 1755, como se constata nas palavras da personagem de um folheto de cordel: “[...] havia bons brincos de diamantes, broxes de muito preço e agora há fitas e pérolas falsas e canquilharia"40. Em outro relato, expõem-se o seguinte pensamento:

Sabem que em Portugal há louca gente, / Que o luxo reina agora, o que he patente, / Carregam seus paquetes, e vem logo/ Com dez mil bugigangas fazer jogo;/ $\mathrm{E}$ lhe corre o dinheiro como hum rio, / E nisto Portugal fica vazio $[\ldots]^{41}$.

\footnotetext{
${ }^{38}$ Queixas de Clorindo ou reprehençam amigável das modas extravagantes (Lisboa: Oficina de Domingos Gonsalves, 1782, p. 12 citado por SANTOS, 2013, p. 156).

${ }^{39}$ Nova Sátyra ao formidável chapeo e anquinhas que apareceram no passeio do cais grande, e a bulha que tiverão os apaixonados de ambos os theatros (Lisboa: Oficina de António Gomes, 1789, p. 9 citado por MOURA, 2010, p. 46).

${ }^{40}$ Novo entremez intitulado $A$ receita de ser peralta ou de casquilharia por força (Lisboa: 1789, p. 10 citado por MOURA, 2010 , p. 58).

${ }^{41}$ Queixas de Clorindo ou reprhençam amigável das modas extravagantes (Lisboa: Oficina de Domingos Gonsalves, 1782, p. 3 citado por MOURA, 2010, p. 43-44).
} 
Esse tipo de assunto era um negócio lucrativo para os autores dos panfletos. Não obstante, os próprios entremezes de cordel $^{42}$ justificam a sua alta popularidade graças às sátiras e críticas bem-humoradas que essas modas sucediam, pois "por causa das modas todos os dias tem o amargo divertimento de se verem apregoadas dos cegos em Farças e Entremezes engraçados, que lhes descobrem expostas ás rizadas do público suas vãs e disparatas loucuras [...]"43.

Todavia, havia escritores de cordel que realmente usavam esse meio para expor sua real preocupação. Na verdade, tais exuberâncias não eram somente bizarras e cafonas, mas, de certa forma, um modo capaz de assolar a esfera familiar e, consequentemente, o próprio país (SANTOS, 2013). Era um contexto em que a nobreza encontrava-se dividida. Enquanto adotavam a moda francesa, a qual representava luxo e poder, esses mesmos trajes também permitiam que o poder da monarquia portuguesa ficasse abalado e volúvel a questionamentos.

Nesse contexto, a moda tornou-se um dos indicadores das modificações então decorrentes. Muitos folhetos de cordel iriam exibir algumas reações e os efeitos que o uso desses trajes provocava na sociedade lusitana.

Diante de tais causas, a literatura de cordel será também um recurso tanto para trazer e comunicar as novidades da moda quanto para criticar esses mesmos trajes, amplamente aceitos e usados pela fidalguia portuguesa.

Além da Igreja, a parcela populacional reacionária anunciava grande resistência pela voz dos moralistas. Não eram somente pensamentos filosóficos meramente escritos e disseminados pelos jornais, folhetos, divagações públicas etc. A moda também expressava e trazia nas novidades estéticas o novo panorama filosófico influenciado pelos princípios iluministas.

Não tardaria muito e a maioria das mulheres portuguesas passaria a aderir ao ímpeto da exteriorização dos valores revolucionários por meio do traje, ainda que, para grande parte das senhoras lusitanas, a real intenção não fosse assumir uma postura revolucionária, mas simplesmente vestir-se de acordo com o bom gosto e de maneira que expressasse poder e status (FERREIRA, 2018).

A moda Império adentrava no gosto das damas aristocratas que passaram a usar vestidos luxuosos, porém com um modelo mais "simples". Seguia um gosto para o exótico e para o clássico, com inspiração na Antiga Grécia. A cintura era alta e geralmente marcada por uma fita, decotes generosos, mangas curtas para os braços ficarem aparentes e uma cauda que variava de tamanho conforme a ocasião. A altura do vestido também diminuíra para deixar mais aparente as pernas e os sapatos, agora mais baixos. Tecidos mais fluidos, finos e transparentes, e xales igualmente fluidos traduziam os novos hábitos do vestuário após a Revolução Francesa.

Mas até os acessórios ganhavam uma avaliação negativa. Sobre o uso dos xales, "são ópio estes de que usão/ Pois julgam ser decência/ Cubrir-se huma Senhora quase toda/ Com hum lençol pintado, e franja à roda"44.

\footnotetext{
${ }^{42}$ Termo utilizado para a representação teatral a partir de textos de cordel.

${ }^{43}$ Nova Palestra em que as Senhoras da Moda entretem as tarde de Sermão (Lisboa: Officina de Domingos Gonsalves, 1786, p. 11 citado por SANTOS, 2013, p. 149).

${ }^{44}$ Opio que dão os Homens e as Senhoras na cidade de Lisboa huns aos outros... (Lisboa: Officina de Simão Thaddeo Ferreira, 1786, p. 7 citado por SANTOS, 2013, p. 158)
} 
Sem demora, os cordéis seguem com suas opiniões acerca da moda Império, alegando que "algumas já não usão das anquinhas,/ Andam todas esguias,/ Meio termo não tem estas damnadas,/ Tísicas hão de ser, ou ser inchadas"45.

Seguindo as palavras de Santos, por menores que fossem as mudanças, ainda que sutis detalhes ou mesmo em uma brusca mudança dos modelos, nada ficaria isento nas opiniões e nos comentários dos escritores de cordéis.

\section{Conclusão}

Se a moda e todas as mudanças que se decorreram nas aparências dos sujeitos foram visivelmente importantes para o convívio e a regulamentação das condutas sociais, a moda também inspirou muitos a escreverem os seus cordéis. Alguns autores portugueses empenharam-se em discorrer como e porque as senhoras portuguesas usavam tais trajes, como se inspiravam e quais eram as suas ambições, enquanto outros eram muito sarcásticos em seus comentários.

Enquanto o surgimento de periódicos lusitanos ainda estava prestes a acontecer, no início do século XIX, tais panfletos foram um tipo de imprensa que tinha como maior estímulo relatar a vida social dos sujeitos e expressar opiniões, sendo elas positivas ou não. 0 luxo e a moda foram os principais temas que levaram os panfletos a se popularizarem. Desde os mais humildes até os mais abastados, todos os apreciavam.

Pelos folhetins, diversas críticas entre defesas e acusações, sátiras e elogios às novas modas alastraram-se pelo país e, de certa forma, ditaram muitas das "normas" do vestuário. Era uma realidade e coexistia em consonância com o discurso moral e estatal. Os moralistas defendiam uma estreita relação entre o traje e a dignidade e até faziam uso de exemplos das Sagradas Escrituras para condenar excessos e profanidades da moda e manter o que compreendiam como estética pessoal de honra.

Além disso, esse assunto passou a ser de interesse do Estado, uma vez que a usurpação de certos símbolos de nobreza podia pôr em xeque a organização da hierarquia social com os excessos sumptuários. Nesse sentido, surgem como intervenção algumas leis, tal como pragmáticas contra o luxo, que estabelecem parâmetros conforme o status de cada sujeito, de modo a garantir certa estabilidade social, evitando gastos excessivos e criticando a ostentação usurpadora.

Houve também escritores de cordéis que se preocuparam com a cultura portuguesa, com seus hábitos próprios, especificamente no que diz respeito ao vestuário. Com a crescente entrada dos costumes franceses e ingleses no continente lusófono, principalmente por meio das modas, perdia-se os valores próprios do que se conhecia como tradicional

\footnotetext{
${ }^{45}$ Modas do tempo Descubertas na Quarta parte dos Opios (Lisboa: Officina de Simão Thaddeo Ferreira, 1788 , p. 5 citado por SANTOS, 2013, p. 156).
} 
no desejo de aparentar aquilo que se considerava como novidade. Sendo assim, a camada conservadora de Portugal também utilizou os cordéis para expor sua resistência quanto aos trajes exageradamente luxuosos que as damas estavam usando. Eles não só quebravam a singeleza do que se conhecia como português, como estimulavam as mulheres a fugir do seu papel social ao aceitar os novos trajes que, indiretamente, também afrontavam a monarquia portuguesa.

As mulheres, sobretudo, passaram a ser mais evidenciadas nesses textos, ainda que, na maioria das vezes, sendo criticadas e ridicularizadas, definindo-as como detentoras de um papel transgressor em vários domínios.

Esses papéis volantes também são importantes para o surgimento e o desenvolvimento da imprensa de moda em Portugal. Enquanto na França, desde o século XVII, já havia periódicos de moda, em terras lusitanas isto só aconteceria em 1807. 0 primeiro jornal de moda português chamaria Correio das Modas, mas enquanto isso, eram os cordéis que faziam a principal tarefa de difundir as novidades e, principalmente, os trajes de bom gosto que chegariam ou que já eram vistos na corte lusitana.

São textos importantíssimos, reveladores de costumes e usos que, por vezes, permitem esboçar uma reconstituição social de épocas anteriores. Esses folhetos são o testemunho da evolução dos trajes femininos das portuguesas de setecentos e de como decorriam tais mudanças.

Esses textos que exaltavam as novidades, principalmente os novos trajes que chegavam a Portugal, ao mesmo tempo eram uma fonte de opiniões conservadoras. A literatura de cordel é um registro e uma prova de uma sociedade que tinha a ambição de originalidade, contudo, manteve boa parte de seus costumes no passado. Eram conservadores nos trajes, ainda que receptíveis às novidades, pois não procuraram criar uma estética própria, mas reproduziram uma aparência já consagrada como superior. E ainda mais reacionários quanto aos tratos com a educação dada às damas.

Em suma, esses textos poéticos ricos em detalhes quanto à sociabilidade e aos trajes, sobretudo quanto à moda consumida, foram de extremo valor para a pesquisa da história da moda de Portugal, e consequentemente da do Brasil, permitindo que estudos nessa linha de pesquisa sejam realizados. 


\section{Referências}

CHANTAL, Suzanne. A vida quotidiana em Portugal ao tempo do terramoto. Lisboa: Edição Livros do Brasil, 1970.

FERREIRA, Manoela Bernardi. Moda e política: influências e consequências deixadas pela moda francesa e inglesa nos trajes de corte de Portugal durante 1789 a 1807. 2018. 158 f.Dissertação (Mestrado em Design de Moda) - Universidade da Beira Interior, Covilhã, 2018.

MAGALHÃES, Alberto da Conceição. A real fábrica das sedas e o comércio têxtil com o Brasil:1734-1822.2010. Disponívelem:https://repositorio.ul.pt/bitstream/10451/4153/1/ ulfl098443_tm.pdf. Acesso em: 19 jul. 2019.

MOURA, Isabel Cristina Silva da Costa. Moda em cordel: aspectos e sugestões da moda em finais de Antigo Regime. 2010. 215 f. Dissertação (Mestrado em Estudos Literários Culturais e Interartes - Culturas Ibéricas) - Faculdade de Letras da Universidade do Porto, Porto, 2010. Disponível em https://repositorio-aberto.up.pt/bitstream/10216/56123/2/ TESEMESISABELMOURA000128562.pdf. Acesso em: 5 jun. 2019.

NOGUEIRA, Carlos. Literatura de cordel portuguesa: história, teoria e interpretação. Lisboa: Apenas Livros, 2003.

SANTOS, Maria José Moutinho. O luxo e as modas em textos de cordel da segunda metade do séc. XVIII. Revista de História, v. 9 (1989), 2013, p. 137-164. Disponível em: https:// repositorio-aberto.up.pt/bitstream/10216/13141/2/6414000069804.pdf. Acesso em: 12 jun. 2019.

\section{Literatura de cordel}

A grande dezordem que teve o Marido com a Mulher Por não querer que trouxesse o Tupete à Marrafe. Lisboa: Officina de António Gomes, 1791.

Compendio de Theologia Moral Evangelica.... Lisboa: Regia Officina Typografica, 1776.

Defeza das Madamas a favor das suas modas.... Lisboa: Officina de António Gomes, 1792.

F. M. G. S. M. (1783). Satyra em louvor das modas ou ESCUDO DA PERALTICE: obra útil a velhos e velhas, meninos e meninas, composta e oferecida aos senhores peraltas e casquilhos de Lisboa. Lisboa: Oficina de Simão Thaddeo Ferreira. 
Gracioza, e divertida farça ou o novo entremez intitulado A defesa das madamas a favor das suas modas, em que deixao convencida a paraltisse dos homens. Lisboa: Oficina de António Gomes, 1742.

Modas do Tempo Descubertas na Quarta parte dos Opios. Lisboa: Officina de Simão Thaddeo Ferreira, 1788.

Nova Palestra em que as Senhoras da Moda entretem as tarde de Sermão. Lisboa: Officina de Domingos Gonsalves, 1786.

Nova Sátyra ao formidável chapeo e anquinhas que apareceram no passeio do cais grande, $e$ a bulha que tiverão os apaixonados de ambos os theatros. Lisboa: Oficina de António Gomes, 1789.

Novo entremez intitulado $A$ receita de ser peralta ou de casquilharia por força. Lisboa: (sem registro da oficina) 1789.

Opio que dão os Homens e as Senhoras na cidade de Lisboa huns aos outros.... Lisboa: Officina de Simão Thaddeo Ferreira, 1786.

Os Peraltas Castigados.... Lisboa: Officina de Domingos Gonsalves, 1786.

Queixas de Clorindo ou reprhençam amigável das modas extravagantes. Lisboa: Oficina de Domingos Gonsalves, 1782.

Relação de huma carta escrita às Peraltas em a qual se lhe apontam os rediculos trastes de que usão.... Lisboa: Officina de Francisco Borges de Sousa, 1787.

Testamento e ultima disposição que de seus ornatos, enfeites, e adornos fez huma França, por causa da nova pragmática, querendo reformarse, deixar o mundo, e entrar em religião, repartindo primeiro pelos conventos pobres as suas melhores gallas, e fazendo outras obras pias, como nelle pode ver ofleumático leitor. Catalunha: Emprensa de Francisco Guevarz, 1751. 